\title{
International Travel in Unsettled Times ${ }^{1}$
}

Mickie Swisher ${ }^{2}$

Many of us must travel for our work. Others of us simply want to travel. While you do need to take certain basic precautions when traveling outside the United States, you can travel safely in today's world.

- Learn about any travel alert issued by the State Department (http://travel.state.gov/). The State Department may issue travel alerts because of unrest or violence, disease, or any other situation that may adversely affect the safety of Americans abroad.

- Take the time to understand the social and economic situation in the nations where you will travel. The Central Intelligence Agency's World Factbook (issued every year) provides summary information about all nations (http://www.odci.gov/cia/publications/factbook/). The State department also provides advice about preparing for a crisis while abroad (http://travel.state.gov/crisismg.html).

- Carry the contact numbers for getting help while abroad. The State Department provides this information (http://travel.state.gov/acs.html).

- Keep a copy of the first two pages of your passport with you and leave one at home in a safe place.

- Make sure you know about any special dangers to your health. The State Department provides lists of doctors and hospitals (http://travel.state.gov/acs.html\#medical) in many nations. Also make sure you check with the Centers for Disease Control and Prevention to learn about health hazards and the vaccinations that you may need to protect your health (http://www.cdc.gov/travel/).

- Medevac insurance is recommended if you will travel to areas where health care is not well developed. This insurance is low cost and provides medical rescue and transport to class A medical facilities if you are in a life threatening situation. The State Department provides a list of medevac providers (http://travel.state.gov/medical.html). Also make sure that your medical insurance covers international claims. If your policy does not cover international claims, make sure that you purchase additional coverage for your stay overseas. Remember that most insurance companies reimburse medical costs incurred overseas. Make sure you have access to the fiscal resources that you might need in case of accident, illness or injury.

- For short trips, make sure that you carry an amply supply of any prescription medications, enough to meet your needs should you have to spend a few extra days abroad.

- Provide associates and family members with detailed information about how to contact you while you are overseas.

1. This document is FCS9196, one of a series of the Department of Family, Youth and Community Sciences, Florida Cooperative Extension Service, IFAS, University of Florida, Gainesville FL 32611. First published: May 2003. Reviewed by: Elizabeth Bolton, Ph.D., Department of Family, Youth and Community Sciences, University of Florida, Gainesville, FL 32611. Please visit the EDIS Web site at http://edis.ifas.ufl.edu

2. Mickie Swisher, Ph.D., associate professor, Department of Family, Youth and Community Sciences, University of Florida, Gainesville FL 32611. 